\title{
ON BECOMING VEGETARIAN
}

\author{
MARK BRAUNSTEIN
}

Providence, Rhode Island

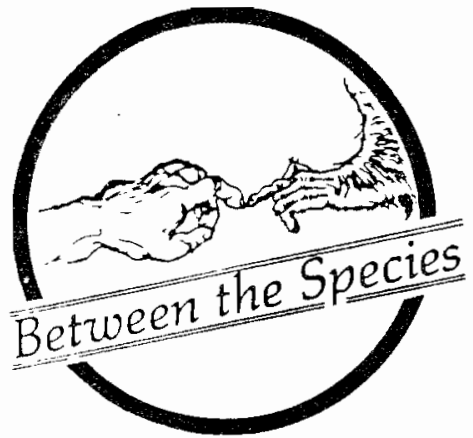

Prelude

Now in the mid-1980's, everyone has heard reasons for becoming vegetarian, whether one has become it or not. But 20 years ago, causes were less well publicized. Those who converted often did so for reasons that they understood little about then and that we still may know little about now.

\section{Act I, Scene I}

A suburban family gathers at the dinner table. The main course is steak. At the bottom of the steak platter gathers a pool of what ma and pa call "juice." Tonight their son, a high school teenager, of a sudden restless that the "juice" is grease and blood, says "No, thanks," he is not so hungry tonight--please pass the carrots.

\section{Act I, Scene II}

No thanks, please pass the string beans. No thanks, please pass the sweet potatoes. No thanks, please pass the bread. For the next half year, he simply is not hungry tonight. Finally, ma and pa inquire, has their son become a vegetarian? Yes, he answers--please pass the salad.

\section{Act I, Scene III}

Out of the closet--and into the cupboard. There he sits at the dinner tale and eats his peanut butter and jelly sandwich. As he eats, he thinks why he will never again drink blood. And he thinks these thoughts:

Because he wants to help animals, he wants to become a veterinarian or a zookeeper--pets and prisoners being the only animals he knows. Because everyday his unknown little friends, calves and lambs, disappear down a million mouths, and why make it a million and one? Because thousands of his brothers become cutthroats in slaughterhouses, since the job pays well, and who pays them? Because he does not want someone to eat his parakeet, he does not want to eat someone else's chicken. Because he likes peanut butter and jelly sandwiches the best.

\section{Act II, Scene I}

He has had no trouble adhering to his yearold diet because his "vegetarianism" includes eating fish and other animals that swim and squirm in the streams and sea. Tonight with friends in a Chinese restaurant, he orders shrimp chow mein. As always when he dines with carnivores, the conversation touches upon his eccentric diet. One of his buddies recounts a lobster dinner: to kill it, the friend threw a live lobster into a pot of boiling water. That it is more humane to pour the boiling water over the lobster to stun it instantly is not the point. The point is that the lobster feels pain, that its inability to reason is no measure of inability to suffer. And with that meal, with half the shrimp on his plate and the other half in his stomach, he vows never again to eat anything that moves--please pass the vegetable chop suey.

\section{Act II, Scene II}

As a kitchen worker in a summer camp, his jobs are many. He mops the congealed blood off the floor of the walk-in refrigerator. He scrubs the pots of their burned grease. He scrapes the hundreds of plates of their leftover mounds of food: half a hog thrown away today, six chickens wasted yesterday, the random pieces of an entire cow tossed

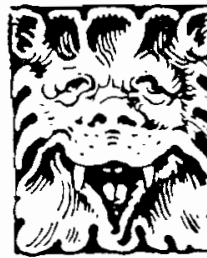
continuec̀ page 47

\section{COMMENT}




\section{ONE PERSON'S EFFORTS}

\author{
INGRID NEWKIRK
}

People for the Ethical

Treatment of Animals
When I was fourteen, I was sitting in my dining room enjoying lunch when I saw an ox cart stop in front of the window. The ox, or bullock, was emaciated, weak, and exhausted. He faltered under the heavy yoke of the cart, no longer able to move, despite the blows striking his back. As I watched, my heart in my mouth, the ox driver dismounted, raised the bullock's tail, and thrust the driving stick--a heavy wooden pole--deep into the animal's rectum. The bullock bellowed, stumbled, and collapsed. As I rushed out, screaming at the driver to stop, I promised myself that when I grew up I would come back to India to help animals escape such treatment.

Each winter I returned to New Delhi from III boarding school in the snowcaps of the Himalayas. For two months, I accompanied my mother from swimming pool to riding lessons to painting classes, from Mother Theresa's horne in Old Delhi--where we stuffed toys for orphans abandoned or lost in the Calcutta riots--to the Leper Charity--where we rolled packs of pills. And always there were the strays that needed feeding, the dogs who scavenged beside the jackals at the dump, the fallen oxen, the animals crying out for the merciful kiss of death. Their image, as they died in the arms of the veterinarian called to the scene, or in mine, made me hate what human beings can do to those they deem unimportant or inferior.

Later, I returned to England, to another life, one of friendships, adventures, and discoveries, a different world. Subsequent travels took me to Switzerland, Germany, and France, then to Spain, Where I idled away the cold months collecting corks on the beaches and reading, as my Indian experience faded from memory.

But, in 1970, a neighborhood incident brought me unexpectedly back into animal protection. I was 21 then, half-heartedly studying for the New York Stock Exchange brokerage exam and whole-heartedly determined

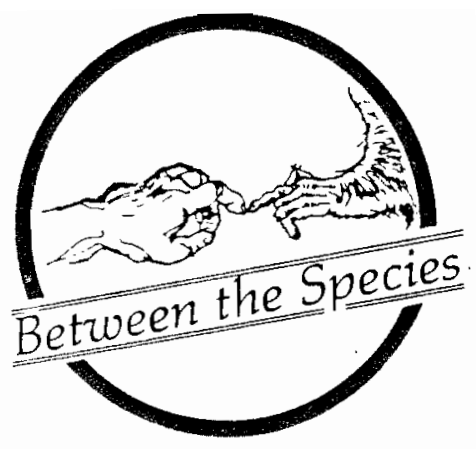

to save enough money to go back to my beachcombing days on the costa del sol.

Living in an old Maryland river settlement called "Seneca," my neighbors were a rowdy bunch who ate squirrel pie and occasionally shot over the fence when they'd had one too many jiggers of rye. When the father of the family died, his brood moved to the big city, leaving behind an interesting collection of auto parts and nineteen cats.

The cats had long been in the habit of dropping their litters in my Volkswagen bus, seeking shelter in my basement, and eating my cats' food, but such a large, permanent addition to my family of cats, chickens, dogs, and the occasional stray sheep, was not in my plans. So, I chose eight to spay and keep, looked up "Animal Shelter" in the Yellow Pages, and drove the rest to what I naively believed would be a temporary sanctuary for them before their placement in loving homes.

Two years later, I had left the brokerage forever, put on a new pair of rubber boots, and reported to work at the first in a string of filthy, mismanaged "dog pounds" I would see in my new career. For me, there had been no choice--I couldn't walk , away after seeing the animals cringing in their cages, watching the staff bang the metal feedbowls on the cement, inhaling the stench of feces no one could be bothered to remove from the runs. They had an opening, and I took the job.

It was almost a year before I saw a chance for long term change. I had spent

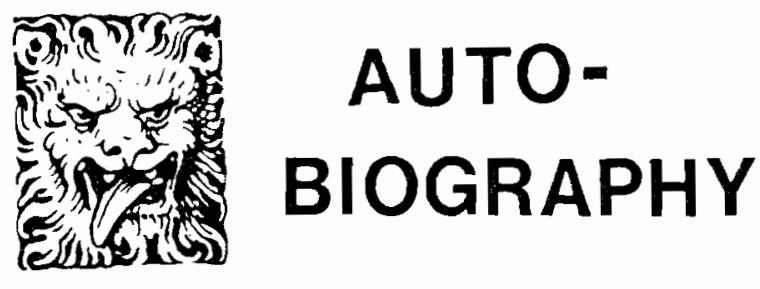


that time learning how other facilities cared for the animals in their charge, discovering what makes animals comfortable and what frightens them. I had managed to implement some changes, but mostly my presence protected the animals from the more sadistic employees' assaults, and I was there to hold then and talk to them while giving them the injections that allowed them to escape it all.

Eleven months into the job, I ran into a television reporter who seemed caring. Taking a deep breath, I told him everything, showing him memos I had written asking the Shelter management to eliminate inhumane practices. The story hit the local news--and I was promptly fired. If I fail in the fight now, I thought, the animals will have no one.

But the news story brought people out of the woodwork. Together with a local councilmember, we fought hard. Every waking moment was spent telephoning people, telling them what the animals endured, begging for their support at the next election. We campaigned in shopping centers; we talked to any stranger willing to listen; we nagged; we pled; and . - we won. The shelter was put under caring managenent, and the abuses ended.

That experience taught me that persistence pays off. If you can keep your commitment through all the tears and anger, you can get things done. There had been so many days when it had seemed hopeless to me, when I had felt out-manned, out-gunned, out-financed. But I had used every waking moment to work for what I believed in, and that had been a bigger card than the opposition could offer. I have never felt intimidated by the enormity of the opposition since.

In the next years, I had the opportunity to initiate an anti-cruelty law enforcement program in that county, to write legislation, to testify on animal protection bills, and to learn all aspects of animal welfare work. one day, driving back late at night from investigating an appalling cruelty case in which a horse had been locked in a stable without food or water until he had died, it suddenly dawned on me that I spent about 1416 hours a day rescuing dogs, cats, raccoons, and horses only to come home to eat lambs, chickens, and cows. I stopped eating animals then. Later, I visited a chicken slaughterhouse on the Delmarva Peninsula and saw first-hand how the animals died. During BETWEEN THE SPECIES those first years, when the smell of Kentucky Fried Chicken might have weakened my new vegetarian resolve, I would remember the screams and the panic of those conscious birds and the look in their eyes as they headed for the knife.

In 1976, I became Director of Cruelty Investigations for the Washington Hurane society/SPCA. There, I had the opportunity to train investigators to use their law enforcenent powers to rescue animals from abusive owners and to improve their living and dying conditions in situations where the law prevented removal. The most important characteristic of a good worker, I believe, is not the amount of education $s$ /he has but the amount of empathy. You cannot "train in" a caring attitude. It was on that basis that I had the pleasure of hiring and working with some wonderful investigators, who had no trouble buming the midnight oil, agonizing over their court cases, and being as innovative as one could imagine in trying to help animals in dire straits.

Perhaps the most valuable lesson I had learned myself and could pass on to trainees was that surrendering to one's own emotions helps no one. The sight of a dog who can barely stand, his ribs protruding like a coat rack, his tail tight beneath his legs, quaking in fear on his chain as he watches his abusive owner approach, can make you want to cry or to react violently. But a conscientious investigator must show no emotion, because she knows that the animal depends on her professionalism to get him out of there permanently. We are in a country where the animal is no more than chattel, and the owner's rights always trump the dog's. The ability to persuade the owner to give up that dog, to use the right degree of pressure, to do one's job without seeming personally involved, can mean everything, including life, to the animal.

Two years later, I was busy trying to change the District of Columbia's dog pound into a decent place for society's animal cast-offs. That facility had been called a "hell-hole for animals" by the washington Post, and with the help of the Washington Humane Society's executive director, Jean Goldenberg, and a Department of Human Services chief, Dr. Martin Levy, I had the opportunity to convert it into a place where animals would no longer tremble, be sold into 
experimentation, or die an agonizing death. It was there that I met Alex Pacheco, with whom I founded People for the Ethical Treatment of Animals (PETA).

Immersed in the animal welfare world, I had only a vague idea of how animals were treated in experimentation and behind other closed doors. Alex gave me a copy of Peter Singer's Animal Liberation and made fun of me for eating dairy products and eggs, the production of which causes animals as much suffering, if not more, than the production of meat. My feelings for animals fell into place.

We learn slowly. I suppose that is the nature of our species. When I was a little girl, growing up in India, I thought that the West was a civilized place, a place where cruelty to animals was a rare thing. And I thought that I would never contribute to causing suffering. Now, I know that the gauge of how much cruelty exists isn't how many bullocks are beaten on their way to market or how many starving dogs one sees on the streets. In America, we hide our cruelty behind steel doors and down railroad sidings. I continue to learn and to change. I can't take back all the years I subsidized products tested on animals, bought fur and leather, ate leg of lamb, and so on, but I have resolved never to dismiss the ideas of those who believe there are other, even subtler forms of cruelties, for later I may realize that they are right.

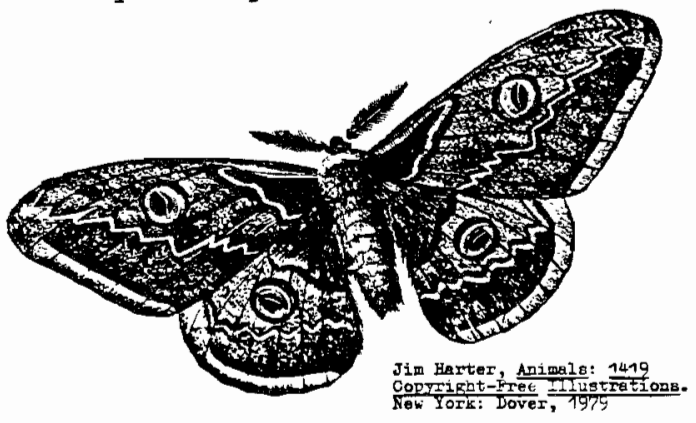

Through the help and generosity of PETA's friends, I have had the opportunity to tell thousands of people what I know about animal abuse and to help them become active in the fight to stop it. If each of us is determined to become a squeaky wheel, resolved to create opportunities to be heard in the grocery line, at the town meeting, in the doctor's office, in letters to the editor, my greatest dream will be a reality: there will be an army of us acting for animals and their world will be a better place.
BRAUNSTEIN

continued from page 44

into the trash by the end of summer. He tolerates his job and every evening washes his hands of the matter. So long as he does not share the meal, his conscience remains as clean as the floors, pots, and dishes. One morning, however, the chore of cracking the fresh eggs for breakfast omelettes causes alarm. Of every hundred, one or two contain a spot of blood--the same blood which initiated his vegetarianism. If it is neither vegetable nor mineral, flesh in a shell must be animal. That morning he vows never again to eat eggs--please pass the oatmeal.

\section{Act II, Scene III}

A college friend invites him to visit the family dairy farm. All forty cows have names and are treated like members of the family. He deeply respects this family, perhaps more than any other he has met. In fact, his love for these people is matched only by theirs for their cows. Yet even under these ideal conditions, the cows deserve better. He sees they are prisoners, allowed only to stand up and sit down for all but an hour of the winter day. Their moos sound like cries of pain. None are truly healthy, which means none are truly happy. Yet these are the best of conditions.

He discovers the worst of conditions awaits the calves for whom the milk is intended. The farm family knows the true cost of milk, the price that must be paid with blood. Every week the truck from the veal farm hauls away their one or two new calves. They greet the truck as though it were a hearse. They regret the doom to which they condenn their calves, and as carnivores, they steadfastly refuse to eat veal. Likewise, as a vegetarian, he now steadfastly refuses to drink milk--please pass the tofu.

\section{Epilogue}

Years pass. All these scenes belong to someone so deep inside him from so long ago that those reasons for his beconing a vegetarian are now feeble compared to the reasons he remains one. A reward he never suspected is good health. And now reward becomes reason. Indeed, his health sets the best example for others to become vegetarians. But health is another story, to save for later, to tell when he reaches 101. 